DOI: $10.26693 / j m b s 06.05 .263$

UDC 616.127-005.4:616-052-08-042.1:616-084

Shuper V. O.', Shuper S. V. ${ }^{2}$, Trefanenko I. V. ${ }^{1}$, Shumko G. I. ${ }^{1}$, Reva T. V. ${ }^{1}$

\title{
Investigation of the Adherence to Prescribed Treatment of the Patients with Coronary Heart Disease
}

\author{
${ }^{1}$ Bucovinian State Medical University, Chernivtsi, Ukraine \\ ${ }^{2}$ Yuriy Fedkovych Chernivtsi National University, Ukraine
}

The purpose of the study was to investigate the adherence to secondary prevention medications among patients with coronary heart disease and identify factors associated with it.

Materials and methods. We examined 40 patients diagnosed with coronary heart disease of more than 50 years old, who were prescribed with optimal medication for 1 year during hospitalization. Patients adherence was defined according to MMS-8 Morisky values for secondary prevention medications prescribed by doctors. Also, questionnaires about individual reasons of non-compliance and for individual patient's opinion about importance and usefulness of knowledge according to risk factors of the increase of cardiovascular mortality were designed and proposed to the patients. Simple descriptive statistics were used to elucidate the characteristics of the patient population and results from individual adherence tools. Final score was analyzed and correlation between patients' data and level of adherence to prescribed treatment were identified. A correlation matrix (using Spearman's coefficient) was reviewed for any evidence of collinearity.

Results and discussion. Our study demonstrated higher level of non-adherence with secondary prevention medications in patients with coronary heart disease $(60.0 \%)$. This fact can be explained by the socioeconomic reasons, less informative strategies from the medical staff to the patients. Severe regress of adherence was demonstrated after discharge from the hospital due to subjective improvement of the patients ' condition with absence of supervision by out-patient specialists.

Demographic characteristics of the patients suggested that some non-modified factors can affect compliance with the prescribed treatment. Better adherence was demonstrated by female married patients with higher educational level, with family history about cardiovascular death. Also, too much prescribed medications with difficult regime of usage with non-adequate out-patient supervision may significantly decrease adherence causing development of complications which may lead to re-hospitalizations and cardiovascular death.

Our investigation demonstrated also non-complete information of the patients about lifestyle and medical risk factors of the cardiovascular mortality increase.

Conclusion. The results of our study can provide useful practical information on the prevalence and severity of non-adherence among patients with coronary heart disease. Analysis of the factors influencing the adherence demonstrated the main reasons from patients and healthcare professionals affecting the level of compliance with the prescribed treatment. The step towards improving adherence can be initiated by the healthcare professional to overcome the patient's concerns about the prescribed medication. It is important to continue personal monitoring of patients by healthcare professionals in the form of regular inspections of intentional and unintentional non-adherence, including factors and reasons that may change and lead to such behavior.

Keywords: non-adherence, coronary heart disease, secondary prevention medications.

Research relation to the plans, programs and department themes. This article is a fragment of scientific-research work "Features of the comorbid course of diseases of internal organs: risk factors, mechanisms of development and mutual burden, pharmacotherapy", the state registration number is 0114 U002475.

Introduction. Nearly $80 \%$ of all cases of deaths all over the world can be caused by chronic diseases, leading the World Health Organization to emphasize prevention of chronic diseases and to increase affordability and accessibility of medications that help extend the lives of people with chronic conditions (World Health Organization, 2017) [1]. The chronic conditions included asthma, hypertension, congestive heart failure, coronary heart disease, cardiac arrhythmias, hyperlipidemia, cerebrovascular disease, arthritis, cancer, chronic kidney disease, chronic obstructive pulmonary disease, diabetes, hepatitis, HIV, and osteoporosis. Approximately half of patients with chronic diseases do not take their medication as prescribed. Across a range of approaches to medication adherence (MA) measurement, researches have shown that poor MA can lead to increased morbidity and mortality, and to significantly increase the cost of healthcare [2]. 
The WHO defines adherence to long term therapy as "the extent to which a person's behavior - taking medication, following a diet, and / or executing lifestyle changes corresponds with agreed recommendations from a healthcare provider" [2, 3]. The term "compliance to medicine" is defined as "the extent to which a patient acts in accordance with the prescribed interval and dose of the dosing regimen" reported as a percentage of prescribed doses taken at the prescribed time interval [3]. Most of the studies on adherence have been undertaken in developed countries. However, healthcare access, cultural beliefs, education about chronic illnesses and the functions of medication, the nature of patient-physician interactions and social support, among many other factors, are very different in developing countries compared to developed countries and may profoundly affect rates of medication adherence [4]. Determinants of MA can be classified into five factors: social-economic, healthcare team- and system-related (reimbursement by health insurance plans), condition-related (severity of symptoms), therapy-related and patient-related factors (forgetfulness) $[1,5]$.

With the improvement of living standards of population, coronary heart disease (CHD) has increasingly become a global health problem and a primary cause of morbidity and premature death worldwide. A number of risk factors contribute to the increased risk of $\mathrm{CHD}$ including hypertension, hyperlipidemia, aging, and diabetes. According to the 2016 World Health Organization global disease assessment report, cardiovascular diseases (CVDs) have been the leading cause of death in the last 10 years [6].

Patients with CHD are typically prescribed secondary prevention medicines (SPMs), such as angiotensin converting enzyme (ACE) inhibitors, angiotensin receptor blockers (ARB), beta-blockers, statins, antiaggregant medications. The benefits of SPMs are well established, and their use is recommended in national and international guidelines. However, non-adherence to medicines remains a key challenge, limiting overall benefits and often leading to poor health outcomes, lower quality of life and increased demand for healthcare [7].

A number of studies have reported high levels of non-adherence among patients with CHD, typically in the range of $33 \%-50 \%$. Non-adherence to SPMs has been associated with a $10 \%-40 \%$ relative increase in the risk of cardiac hospitalization and a $50 \%-80 \%$ relative increase in mortality [6, 7].

Non-adherence is often a hidden problem, not recognized by medical staff and not necessarily disclosed by patients. Healthcare professionals should assess, elicit and explore patients' beliefs and experiences with their medications to help them make informed choices and decrease non-adherence. This requires the use of specific tools that can be deployed in clinical practice to explore and address barriers to proper medications usage $[8,9]$.

The purpose of the work was to investigate the adherence to secondary prevention medications among patients with coronary heart disease and identify factors associated with it.

Materials and methods. We examined 40 patients diagnosed with CHD using complex medical treatment during hospitalization. All patients also were encouraged to comply with drug and healthy lifestyles. The inclusion criteria were age more than 50 years old, diagnosed stable CHD that has been treated with optimal medications for 1 year. The demographic data included age, gender, educational level, marital status and family history of cardiovascular death. The data was completed with a patient medical history obtained from medical records regarding the history of diabetes mellitus, hypertension, heart failure, and stroke.

Patients' adherence was defined according to MMS-8 Morisky values for secondary prevention medications prescribed by doctors, with a value $<6$ defined as poor adherence, and $\geq 6$ defined as good adherence. The questionnaire about individual reasons of non-compliance uses six statements about forgetting to take medicines, not taking medicines for reasons other than forgetfulness, changing medicines due to feeling unwell or feeling that the condition is better controlled and feeling hassled about sticking to their treatment plan [10].

In addition, data regarding the history of treatment, intervention, and echocardiography were also obtained from the medical record added to the questionnaire data. Simple descriptive statistics were used to elucidate the characteristics of the patient population and results from individual adherence tools. The questionnaire for individual patient's opinion about importance and usefulness of knowledge according to risk factors of the increase cardiovascular mortality was designed and proposed to the patients (Table 1).

Final score was analyzed, and correlation between patients' data and level of adherence to prescribed treatment were identified. A correlation matrix (using Spearman's coefficient) was reviewed for any evidence of collinearity.

Results and discussion. The demographic profile of investigated patients was summarized in Table 2. The median age was $65.3 \pm 4.7$ years (range: $50-84), 23$ patients $(57.5 \%)$ were male, 17 patients $(42.5 \%)$ were female. The average total number of medications prescribed to patients (including non-secondary prevention medications) was 7 (range: 4-12), and the average number of individual daily doses was 6 (range 3-18). The median number of daily administration times was twice daily (range: 1-4 times daily). 
Table 1 - The questionnaire about importance and usefulness of knowledge according to risk factors of the increase cardiovascular mortality

\begin{tabular}{|c|c|c|c|c|c|c|}
\hline & & $\begin{array}{l}\text { Absolutely } \\
\text { agree, } \\
5\end{array}$ & $\begin{array}{l}\text { Partially } \\
\text { agree, } \\
4\end{array}$ & $\begin{array}{l}\text { No } \\
\text { opinion, } \\
3\end{array}$ & $\begin{array}{c}\text { Disagree } \\
2\end{array}$ & $\begin{array}{l}\text { Absolutely } \\
\text { disagree, } \\
1\end{array}$ \\
\hline 1 & $\begin{array}{l}\text { High blood pressure level increases cardio- } \\
\text { vascular mortality }\end{array}$ & & & & & \\
\hline 2 & $\begin{array}{l}\text { High blood sugar level increases cardiovas- } \\
\text { cular mortality }\end{array}$ & & & & & \\
\hline 3 & $\begin{array}{l}\text { High blood cholesterol level increases car- } \\
\text { diovascular mortality }\end{array}$ & & & & & \\
\hline 4 & $\begin{array}{l}\text { High body weight level increases cardiovas- } \\
\text { cular mortality }\end{array}$ & & & & & \\
\hline 5 & $\begin{array}{l}\text { Low level of physical activity increases car- } \\
\text { diovascular mortality }\end{array}$ & & & & & \\
\hline 6 & Smoking increases cardiovascular mortality & & & & & \\
\hline 7 & $\begin{array}{l}\text { Drinking alcohol increases cardiovascular } \\
\text { mortality }\end{array}$ & & & & & \\
\hline 8 & $\begin{array}{l}\text { Skipping or unauthorized cancellation of } \\
\text { prescribed medications increases cardio- } \\
\text { vascular mortality }\end{array}$ & & & & & \\
\hline
\end{tabular}

Table 2 - Patients` characteristics

\begin{tabular}{|c|c|c|}
\hline \multicolumn{2}{|r|}{ Characteristics } & $\begin{array}{c}\text { Patients } \\
(\mathrm{N}=40)\end{array}$ \\
\hline \multicolumn{2}{|c|}{ Age (years), median } & $\begin{array}{c}65.3 \pm 4.7 \\
\text { years }\end{array}$ \\
\hline \multicolumn{2}{|l|}{ Male, n (\%) } & $23(57.5)$ \\
\hline \multicolumn{2}{|l|}{ Female, n (\%) } & $17(42.5)$ \\
\hline \multirow{2}{*}{ Educational level } & High & $18(40.0)$ \\
\hline & Secondary & $22(60.0)$ \\
\hline \multirow{2}{*}{ Marital status } & Married & $33(82.5)$ \\
\hline & Single & $7(17.5)$ \\
\hline \multicolumn{2}{|c|}{ Family history of cardiovascular death } & $11(27.5)$ \\
\hline \multicolumn{3}{|c|}{ Underlying conditions/comorbidities, n (\%) } \\
\hline \multicolumn{2}{|c|}{ Myocardial infarction } & $7(17.5)$ \\
\hline \multicolumn{2}{|c|}{ Arterial hypertension } & $34(85.0)$ \\
\hline \multicolumn{2}{|l|}{ COPD } & $8(20.0)$ \\
\hline \multicolumn{2}{|c|}{ Diabetes Mellitus } & $22(55.0)$ \\
\hline \multicolumn{3}{|c|}{ Secondary prevention medications prescribed, $\mathrm{n}(\%)$} \\
\hline \multicolumn{2}{|l|}{ Statin } & $32(80.0)$ \\
\hline \multicolumn{2}{|l|}{ Antiaggregant } & $40(100.0)$ \\
\hline \multicolumn{2}{|l|}{ Beta-blocker } & $24(60.0)$ \\
\hline \multicolumn{2}{|l|}{ ACE inhibitor } & $31(77.5)$ \\
\hline \multicolumn{2}{|l|}{ ARA } & $9(22.5)$ \\
\hline \multicolumn{2}{|c|}{ Total number of medications, median (range) } & $7(4-12)$ \\
\hline \multicolumn{2}{|c|}{ Number of individual daily doses, median (range) } & $6(3-18)$ \\
\hline \multicolumn{2}{|c|}{ Number of daily administration times, median (range) } & $2(1-4)$ \\
\hline \multicolumn{3}{|c|}{ Dosing frequency of medicines, $\mathrm{n}(\%)$} \\
\hline \multicolumn{2}{|l|}{ All once daily } & $18(45.0)$ \\
\hline \multicolumn{2}{|c|}{ At least one medicine taken twice daily } & $16(40.0)$ \\
\hline \multicolumn{2}{|c|}{ At least one medicine taken more than twice daily } & $6(15.0)$ \\
\hline
\end{tabular}

Patients` adherence for secondary prevention medications prescribed by specialists we assessed according to MMS-8 Morisky values. Results (Table 3 ) demonstrate total prevalence of non-adherent patients (60\%). Inside of them, more often non-adherence corresponded to male sex, younger age, not married, low educational level, comorbidities, more than 5 medications prescribed.

Within non-adherent patients we analyzed the most often reasons of their deficient compliance to prescribed secondary prevention medications (Table 4). It was found out that mostly patients stopped or change the regime of using prescribed medications after improvement of their condition (usually after discharge from the hospital). Also, in more than half of respondents, financial problems caused non-adherence appearance. Most non-adherent patients demonstrated more than one significant reason of deficient compliance.

We analyzed results of the questionnaire for individual patient's opinion about importance and usefulness of knowledge according to risk factors of the increase of cardiovascular mortality (Table 5). It was shown, that adherent patients significantly stronger agreed with proposed statements about risk factors in comparing with non-adherent respondents. Female married persons with high education level and comorbidities demonstrated almost always complete agreement with statements, which highly correlated with higher compliance to prescribed secondary prevention medications for the treatment of CHD. 
Table 3 - Characteristics of the patients adherence for secondary prevention medications

\begin{tabular}{|l|c|c|c|}
\hline \multicolumn{2}{|c|}{ Characteristics } & $\begin{array}{c}\text { Adher- } \\
\text { ence, } \\
\text { n (\%) }\end{array}$ & $\begin{array}{c}\text { Non- } \\
\text { adhernce, } \\
\text { n (\%) }\end{array}$ \\
\hline Male & $6(26.1)$ & $17(73.9)$ \\
\hline Female & $10(58.8)$ & $7(41.2)$ \\
\hline \multirow{2}{*}{$\begin{array}{l}\text { Educational } \\
\text { level }\end{array}$} & High & $10(55.6)$ & $8(44.4)$ \\
\cline { 2 - 4 } & Secondary & $6(27.3)$ & $16(72.7)$ \\
\hline $\begin{array}{l}\text { Marital } \\
\text { status }\end{array}$ & Married & $14(42.4)$ & $19(57.6)$ \\
\cline { 2 - 4 } $\begin{array}{l}\text { Family history } \\
\text { of cardiovascular death }\end{array}$ & $2(28.6)$ & $5(71.4)$ \\
\hline Comorbidities & $12(32.7)$ & $3(27.3)$ \\
\hline $\begin{array}{l}\text { Number of } \\
\text { medications } \\
\text { prescribed }\end{array}$ & $>5$ & $7(30.4)$ & $22(64.7)$ \\
\cline { 2 - 4 } & $\leq 5$ & $9(52.9)$ & $8(47.1)$ \\
\hline \multicolumn{2}{|l}{} \\
\hline
\end{tabular}

Table 4 - Reasons of individual patient's non-adherence to prescribed secondary prevention medications

\begin{tabular}{|l|c|}
\hline \multicolumn{1}{|c|}{ Reason } & $\begin{array}{c}\text { Non-adherent } \\
\text { patients } \\
\text { (n = 24) }\end{array}$ \\
\hline Forgetfulness & $12(50.0 \%)$ \\
\hline $\begin{array}{l}\text { Worry that medications will do more } \\
\text { harm than good }\end{array}$ & $10(41.7 \%)$ \\
\hline $\begin{array}{l}\text { Stopped medications after feeling } \\
\text { worse }\end{array}$ & $7(29.2 \%)$ \\
\hline $\begin{array}{l}\text { Not convinced enough about the im- } \\
\text { portance of medications }\end{array}$ & $11(45.8 \%)$ \\
\hline $\begin{array}{l}\text { Stopped medications after improve- } \\
\text { ment of condition }\end{array}$ & $18(75 \%)$ \\
\hline $\begin{array}{l}\text { Felt financially burdened by cost of } \\
\text { medications }\end{array}$ & $14(58.3 \%)$ \\
\hline
\end{tabular}

Table 5 - Results of the questionnaire for individual patient's opinion about importance and usefulness of knowledge according to risk factors of the increase of cardiovascular mortality

\begin{tabular}{|c|c|c|c|}
\hline \multicolumn{2}{|c|}{ Characteristics } & $\begin{array}{l}\text { Adherence, } \\
\text { M } \pm m \text { score }\end{array}$ & 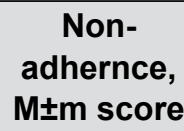 \\
\hline \multicolumn{2}{|l|}{ Male } & $30.3 \pm 2.7$ & $22.3 \pm 3.2$ * \\
\hline \multicolumn{2}{|l|}{ Female } & $34.6 \pm 2.2$ & $28.4 \pm 3.7$ \\
\hline \multirow{2}{*}{$\begin{array}{l}\text { Educational } \\
\text { level }\end{array}$} & High & $35.1 \pm 3.2$ & $24.5 \pm 2.4^{*}$ \\
\hline & Secondary & $28.6 \pm 2.5$ & $20.2 \pm 1.7$ \\
\hline \multirow{2}{*}{ Marital status } & Married & $36.6 \pm 1.3$ & $18.4 \pm 3.3^{*}$ \\
\hline & Single & $27.3 \pm 2.8$ & $16.2 \pm 4.1$ \\
\hline \multicolumn{2}{|c|}{$\begin{array}{l}\text { Family history } \\
\text { of cardiovascular death }\end{array}$} & $32.3 \pm 4.7$ & $21.6 \pm 2.2$ * \\
\hline \multicolumn{2}{|l|}{ Comorbidities } & $34.3 \pm 4.5$ & $14.6 \pm 2.8$ * \\
\hline \multirow{2}{*}{$\begin{array}{l}\text { Number of } \\
\text { medications } \\
\text { prescribed }\end{array}$} & $>5$ & $33.3 \pm 2.7$ & $16.6 \pm 3.1$ * \\
\hline & $\leq 5$ & $28.3 \pm 3.2$ & $21.9 \pm 2.7$ \\
\hline
\end{tabular}

Note: * difference is significant $(p<0.05)$.
Our study demonstrated higher level of non-adherence with secondary prevention medications in patients with $\mathrm{CHD}(60.0 \%)$ than was broadly consistent in the modern literature data $[7,8,11,12]$. This fact can be explained by the socioeconomic reasons, less informative strategies from the medical staff to the patients, especially general practitioners. Severe regress of adherence was demonstrated after discharge from a hospital due to subjective improvement of the patients' condition and absence of close supervision by out-patient specialists.

Demographic characteristics of the examined patients suggested that some non-modified factors can affect compliance with the prescribed treatment. Better adherence was demonstrated by female patients with higher educational level, if they were married, known about negative consequences of cardiovascular diseases in their families.

If analyze modified affecting reasons, it could be suggested that too many prescribed medications with difficult regime of usage (twice or trice daily) with non-adequate outpatient supervision may significantly decrease adherence causing development of complications, that may lead to re-hospitalizations and cardiovascular death, which corresponds to literature data $[13,14]$.

Our investigation demonstrated also non-complete information of the patients with $\mathrm{CHD}$ about lifestyle and medical risk factors of the cardiovascular mortality increase. This fact may represent insufficient work of medical personnel in special training of patients for secondary prevention of cardiovascular pathology, which also negatively affects adherence to the treatment $[15,16]$.

In addition, according to the literature data, adherence may change over time, and shifting beliefs about medications can often underlie this: over the first year of treatment, around $20 \%$ of patients may experience a significant increase in concern about their complex treatment [17]

Conclusion and perspective for further research. Despite a rather small and short-term study, received results can provide useful practical information on the prevalence and severity of adherence disorders among patients with coronary heart disease.

Analysis of the factors influencing the adherence of cardiovascular patients has demonstrated the main reasons from patients and healthcare professionals affecting the level of compliance with the prescribed treatment.

The step towards improving adherence can be initiated by the healthcare professional to overcome the patient's concerns about the prescribed medication (taking into account the amount and level of information tailored to individual needs) and to improve understanding of the disease and medication, which 
will help solve the problem of clear continuation of prescribed treatment.

Non-compliance with treatment may not be directed to the whole complex but to partial drugs. This necessitates personal monitoring of patients by healthcare professionals in the form of regular in- spections of intentional and unintentional non-adherence, including factors and reasons that may change and lead to such behavior. Concerns and difficulties with medication should be addressed even to patients who have the adherent behavior to prescribed treatment.

\section{References}

1. Bassett SM, Schuette SA, O'Dwyer LC, Moskowitz JT. Positive affect and medication adherence in chronic conditions: A systematic review. Health Psychol. 2019; 38(11): 960-74. PMID: 31368717. PCMID: PMC6800780. doi: 10.1037/hea0000778

2. Brown MT, Bussell JK. Medication Adherence: WHO Cares? Mayo Clin Proceed. 2011;86:304-14. PMID: 21389250. PCMID: PMC3068890. doi: 10.4065/mcp.2010.0575

3. Osterberg L, Blaschke T. Adherence to medication. N Eng J Med. 2005; 353(5): 487-97. PMID: 16079372. doi: 10.1056/NEJMra050100

4. Kardas $P$, Lewek $P$, Matyjaszczyk M. Determinants of patient adherence: a review of systematic reviews. Frontiers Pharmacol. 2013; 4: 91. PMID: 23898295. PCMID: PMC3722478. doi: 10.3389/fphar.2013.00091

5. Cramer JA, Roy A, Burrell A, Fairchild CJ, Fuldeore MJ, Ollendorf DA, et al. Medication Compliance and Persistence: Terminology and Definitions. Val Health. 2008; 11: 44-7. PMID: 18237359. doi: 10.1111/j.15244733.2007.00213.x

6. Karimullah MDH, Rohman MS, Adriyanto T, Tjahjono CT, Widito S. Community-based Cardiac Rehabilitation Improved Adherence to Medication, Quality of Life and Rehospitalization Among Stable Coronary Artery Patients: A Cohort Study. Heart Sci J. 2020; 1(2): 24-31. doi: 10.21776/ub.hsj.2020.001.02.5

7. Khatib R, Marshall K, Silcock J, Forrest C, Hall AS. Adherence to coronary artery disease secondary prevention medicines: exploring modifiable barriers. Open Heart. 2019; 6: e000997. PMID: 31354954. PCMID: PMC6615814. doi: 10.1136/openhrt-2018-000997

8. Tian Y, Deng P, Li B, Wang J, Li J, Huang Y, Zheng Y. Treatment models of cardiac rehabilitation in patients with coronary heart disease and related factors affecting patient compliance. Rev Cardiovasc Med. 2019; 20(1): 2733. PMID: 31184093. doi: 10.31083/j.rcm.2019.01.53

9. Dhar L, Dantas J, Ali M. A Systematic Review of Factors Influencing Medication Adherence to Hypertension Treatment in Developing Countries. Open J Epidemiol. 2017; 7: 211-50. doi: 10.4236/ojepi.2017.73018

10. Morisky DE, Ang A, Krousel $\square$ Wood M, Ward HJ. Predictive validity of a medication adherence measure in an outpatient setting. J Clin Hypertens. 2008; 10(5): 348-354. PMID: 18453793. PCMID: PMC2562622. doi: 10.1111/j.1751-7176.2008.07572.x

11. De Vera MA, Bhole V, Burns LC, Lacaille D. Impact of statin adherence. Br J Clin Pharmacol. 2014; 78: 684-98. PMID: 25364801. PCMID: PMC4239963. doi: 10.1111/bcp.12339

12. Rasmussen JN, Chong A, Alter DA. Relationship between adherence to evidence-based pharmacotherapy and long-term mortality after acute myocardial infarction. JAMA. 2007; 297: 177-86. PMID: 17213401. doi: 10.1001/ jama.297.2.177

13. Nobre M, Domingues R. Patient adherence to ischemic heart disease treatment. Rev Assoc Med Brasil. 2017; 63(3): 252-60. PMID: 28489132. doi: 10.1590/1806-9282.63.03.252

14. McHorney CA. The Adherence Estimator: a brief, proximal screener for patient propensity to adhere to prescription medications for chronic disease. Curr Med Res Opin. 2009; 25(1): 215-38. PMID: 19210154. doi: 10.1185/03007990802619425

15. Santo K, Chow CK, Thiagalingam A, et al. MEDication reminder APPs to improve medication adherence in Coronary Heart Disease (MedApp-CHD) Study: a randomised controlled trial protocol. BMJ Open. 2017; 7: e017540. PMID: 28993388. PCMID: PMC5640083. doi: 10.1136/bmjopen-2017-017540

16. Alm-Roijer C, Stagmo M, Ude G, Erhardt L. Better knowledge improves adherence to lifestyle changes and medication in patients with coronary heart disease. Eur J Cardiovasc Nurs. 2004; 3: 321- 30. PMID: 15572021. doi: 10.1016/j.ejcnurse.2004.05.002

17. KubicaA, KosobuckaA, Fabiszak T, Gorog DA, Siller-Matula JM. Assessment of adherence to medication in patients after myocardial infarction treated with percutaneous coronary intervention. Is there a place for newself-reported questionnaires? Curr Med Res Opin. 2019; 35: 341-9. PMID: 30091642. doi: 10.1080/03007995.2018.1510385 
УДК 616.127-005.4:616-052-08-042.1:616-084

ИССЛЕДОВАНИЕ ПРИВЕРЖЕННОСТИ К ЛЕЧЕНИЮ ПАЦИЕНТОВ

С ИШЕМИЧЕСКОЙ БОЛЕЗНЬЮ СЕРДЦА

Шупер В. О., Шупер С. В., Трефаненко И. В., Шумко Г. И., Рева Т. В.

Резюме. Целью работы было исследование приверженности к препаратам вторичной профилактики среди пациентов с ишемической болезнью сердца и выявление влияющих факторов.

Материал и методы. Было обследовано 40 пациентов с диагнозом ишемическая болезнь сердца в возрасте старше 50 лет, которым было назначено оптимальное лечение в течение 1 года после госпитализации. Приверженность пациентов к лечению определялась по шкале MMS-8 Morisky для препаратов вторичной профилактики. Были разработаны и предложены пациентам анкеты об индивидуальных причинах нарушения приверженности к терапии и для оценки индивидуального мнения пациента о важности и полезности знаний о факторах риска увеличения смертности от сердечно-сосудистых заболеваний. Простая описательная статистика использовалась для оценки демографических характеристик пациентов и результатов оценки приверженности к терапии. Был проанализирован суммированный бал по опросникам и выявлена корреляция между данными анкет пациентов и уровнем приверженности к назначенному лечению.

Результаты. Данное исследование продемонстрировало высокий уровень несоблюдения режима лечения вторичными профилактическими препаратами у пациентов с ишемической болезнью сердца (60,0\%). Этот фракт можно объяснить социально-экономическими причинами, недостаточным информированием медицинским персоналом пациентов по поводу рисков нарушения режима назначенной терапии. Серьезный регресс приверженности был продемонстрирован после выписки из больницы из-за субъективного улучшения состояния пациентов при отсутствии наблюдения со стороны специалистов поликлинического звена.

Демографические характеристики пациентов свидетельствуют о том, что некоторые немодифицируемые фракторы могут влиять на соблюдение режима лечения. Лучшая приверженность была продемонстрирована женщинами, состоящими в браке, с более высоким уровнем образования, имеющими негативный семейный анамнез по поводу смерти от сердечно-сосудистых заболеваний. Кроме того, избыточное количество прописываемых лекарств с усложненным режимом их применения и неадекватным амбулаторным наблюдением может значительно снизить приверженность к лечению, вызывая развитие осложнений, которые могут привести к повторной госпитализации и смерти от сердечно-сосудистых заболеваний.

Исследование показало также недостаточное информирование пациентов о нездоровом образе жизни и медицинских факторах риска повышения смертности от сердечно-сосудистых заболеваний.

Выводы. Результаты данного исследования могут предоставить полезную практическую информацию о распространенности и серьезности несоблюдения режима лечения среди пациентов с ИБС. Анализ факторов, влияющих на приверженность, выявил основные причины со стороны пациентов и медицинских работников, влияющие на уровень соблюдения назначенного лечения. Улучшение приверженности может быть инициировано медицинскими работниками для преодоления сомнений пациента по поводу назначенного лекарства. Важно продолжать персональный мониторинг пациентов со стороны медицинских работников в фрорме регулярных проверок преднамеренного и непреднамеренного несоблюдения режима лечения, включая факторы и причины, которые могут привести к такому поведению.

Ключевые слова: несоблюдение режима лечения, ишемическая болезнь сердца, препараты вторичной профилактики.

УДК 616.127-005.4:616-052-08-042.1:616-084

ДОСЛІДЖЕННЯ ПРИХИЛЬНОСТІ ДО ЛІКУВАННЯ ПАЦІЄНТІВ

3 ІШЕМІЧНОЮ ХВОРОБОЮ СЕРЦЯ

Шупер В. О, Шупер С. В., Трефаненко І. В., Шумко Г. І., Рева Т. В.

Резюме. Метою роботи було дослідження прихильності до препаратів вторинної профрілактики серед пацієнтів з ішемічною хворобою серця і виявлення факторів, що на неї впливають.

Матеріал та методи. Було обстежено 40 пацієнтів з діагнозом ішемічна хвороба серця у віці старше 50 років, яким було призначено оптимальне лікування протягом 1 року після госпіталізації. Прихильність пацієнтів до лікування визначалася за шкалою MMS-8 Morisky для препаратів вторинної профілактики. Розроблені і запропоновані пацієнтам анкети про індивідуальні причини порушення прихильності до терапії і для оцінки персональної думки пацієнта про важливість і корисність знань про чинники ризику збільшення смертності від серцево-судинних захворювань. Проста описова статистика використову- 
валася для аналізу демографічних характеристик пацієнтів і результатів оцінки прихильності до терапії. Проаналізовано підсумований бал по опитувальникам, і виявлена кореляція між даними анкет пацієнтів та рівнем прихильності до призначеного лікування.

Результати. Дане дослідження продемонструвало високий рівень недотримання режиму лікування препаратами вторинної профрілактики у пацієнтів з ішемічною хворобою серця (60,0\%). Цей факт можна пояснити соціально-економічними причинами, недостатнім інформуванням медичним персоналом пацієнтів з приводу ризиків порушення режиму призначеної терапії. Серйозний регрес прихильності був продемонстрований після виписки з лікарні через відчуття суб'єктивного поліпшення стану пацієнтів при відсутності спостереження з боку фахівців поліклінічної ланки.

Демографрічні характеристики пацієнтів свідчать про те, що деякі немодіфіковані чинники можуть впливати на дотримання режиму лікування. Краща прихильність була продемонстрована жінками, які перебувають у шлюбі, з більш високим рівнем освіти, які мають негативний сімейний анамнез з приводу смерті від серцево-судинних захворювань. Крім того, надмірна кількість призначених ліків з ускладненим режимом їх застосування і неадекватним амбулаторним наглядом може значно знизити прихильність до лікування, викликаючи розвиток ускладнень, які можуть призвести до повторної госпіталізації і смерті від серцево-судинних захворювань.

Дослідження показало також недостатнє інформування пацієнтів про нездоровий спосіб життя та медичні фрактори ризику підвищення смертності від серцево-судинних захворювань.

Висновки. Результати проведеного дослідження можуть надати корисну практичну інфоормацію про поширеність і серйозність недотримання режиму лікування серед пацієнтів з ішемічною хворобою серця. Аналіз факторів, що впливають на прихильність, виявив основні причини з боку пацієнтів і медичних працівників, що впливають на рівень дотримання призначеного лікування. Поліпшення прихильності може бути ініційовано медичними працівниками для подолання сумнівів пацієнта з приводу медикаментозного лікування. Важливо продовжувати персональний моніторинг пацієнтів з боку медичних працівників у формі регулярних перевірок навмисного і ненавмисного недотримання режиму лікування, включаючи фрактори і причини, які можуть привести до такої поведінки.

Ключові слова: недотримання режиму лікування, ішемічна хвороба серця, препарати вторинної профрілактики.

\section{ORCID and contributionship:}

Sergij V. Shuper : 0000-0002-4883-9273 A, B, D, F

Vira O. Shuper : 0000-0001-9881-1757 A, B, D, F

Iryna V. Trefanenko : 0000-0002-7751-9412 B, E,F

Galina I. Shumko : 0000-0002-2087-9396 B, D, E

Tetyana V. Reva : 0000-0002-7047-5795 B, D, E

A - Work concept and design, B - Data collection and analysis,

C - Responsibility for statistical analysis, D - Writing the article,

E - Critical review, F - Final approval of the article

\section{CORRESPONDING AUTHOR}

\section{Vira O. Shuper}

Chernivtsi, Bukovinian State Medical university

Department of internal medicine, clinical pharmacology and occupational diseases

9, Vorobkevicha St., apt. 32, Chernivtsi 58001, Ukraine

tel: +380504759240, e-mail: sssrlug@gmail.com

The authors of this study confirm that the research and publication of the results were not associated with any conflicts regarding commercial or financial relations, relations with organizations and/or individuals who may have been related to the study, and interrelations of coauthors of the article. 